\title{
Payment Persistence of Participants in Turkish Private Pension Scheme and Gender Differences
}

\author{
Yilmaz Yildiz ${ }^{1}$, Özgür Arslan-Ayaydin ${ }^{2} \&$ Mehmet Baha Karan ${ }^{1}$ \\ ${ }^{1}$ Hacettepe University, Ankara, Turkey \\ ${ }^{2}$ University of Illinois at Chicago, Chicago, United States \\ Correspondence: Yilmaz Yildiz, Hacettepe University, Department of Business Administration, 06800, Beytepe, \\ Çankaya, Ankara, Turkey. Tel: 903-122-978-700. E-mail: yilmazyildiz@ hacettepe.edu.tr
}

Received: August 15, 2016

Accepted: September 9, 2016

Online Published: September 25, 2016

doi:10.5539/ijef.v8n10p159

URL: http://dx.doi.org/10.5539/ijef.v8n10p159

\begin{abstract}
By considering the gender differences, this paper investigates the impacts of socioeconomic and demographic attributes on the persistence of individuals' payments to their own private pension schemes. With separating the individuals according to their genders, we study totally 6,025 participants from 2004 to 2012. For men, it is found that amount of payment, age, marital status, education, being located in the industrial and financial center of Turkey, higher risk tolerance and total period remained in the system are all positively associated with the likelihood of being a persistent payer. For women, the findings for all the attributes align to those for men except for the marital status and being located in the industrial and financial center of Turkey. Overall, our results are plausible for financial institutions and policy makers that are typically sensitive to the payment persistence of the participants to the private pension schemes.
\end{abstract}

Keywords: private pension, payment persistence, gender, investment, Turkey

\section{Introduction}

There is a worldwide trend towards defined contribution savings plan as an alternative and/or complement to the public pension systems. This is mainly due to aging of population in a global scale and thus worries over the replacement rate for the sustainability of defined benefit plans. Turkey gave a head start to the private pension scheme in 2003 by also maintaining its government pension mechanism. The purposes of the initiation of the private pension system is not only to provide additional income to individuals but also to surge national savings into long term investments and thus deepen domestic financial markets (Elveren, 2013), also reduce the predominant share of foreign institutional investors in the stock market capitalization of Turkey (Akın, 2012).

The voluntary saving scheme in Turkey is neither a form of employment-based profit sharing arrangement nor an employer-sponsored pension. The investor has a choice regarding the type of assets in which the accumulation is invested and can easily find out its value at any time. Participants may pay any amount of contribution and investment funds managed by individual pension participants allow them to consider a range of investment strategies, selecting portfolios suited to their time horizon and risk tolerance.

Payment after the due date or a missing payment is a common problem for all private pension plans in Turkey. Penalty fee or interest payments are worldwide applications to enforce participants to ensure payment persistency. However, the problem is expanding, mainly due to application of very low penalties for late payments by the Turkish legislation. The report of Pension Monitoring Center of Turkey indicates that this leads to a significant loss for not only system participants but also for the national economy (Individual Pension System Progress Report of Turkey, 2010).

The aim of this study is to investigate the impacts of demographic and socioeconomic attributes on the payment persistency of participants to a private pension scheme in Turkey. In other words, we analyze the influence of the demographic and socioeconomic factors on the discrepancy between declared payments on the pension contract and actual payments of the individuals. The socioeconomic attributes and demographics of private pension subscribers raise important questions for public policy, particularly in the light of the recent trend toward self-directed pension accounts. With the better understanding of the impact of these attributes on the observed payment patterns, interventions can be more effectively designed for overall financial well-being of citizens and 
capital allocation to domestic financial markets can be better managed. Furthermore, the results for Turkey provide generalizability for comparable emerging markets with recent attempts of institutionalizing private pension schemes.

To our knowledge, this is the first study on the payment persistency of the private pension scheme participants for Turkey. Previously, Kayam, Parkin, and Celiktopuz (2013) have shown the impacts of demographic factors on a participant's premature departure from the Turkish private pension scheme. In a similar vein, for Turkey, Arslan and Karan (2010) and Kucuktalasli, Arslan-Ayaydin and Karan (2012) highlight the importance of the impact of demographic and socioeconomic factors on consumer credit risks.

The second unique contribution of this study is to look at gender differences in the participant's persistence in payments to individual private pension schemes. By covering a database for the year 2004, Elveren and Hsu (2007) and Elveren (2008) were the first to study the gender dimension of social security in Turkey.

The remainder of this paper is as follows; the following section explains the motivation of the study and the third section explains the database and methodology. In the fourth section we present the results and section five concludes the paper.

\section{Motivation and Literature Review}

While still maintaining its government pension system, Turkey puts a serious effort on promoting the individuals to the private pension scheme. Reduction in real interest rates, coming down from almost $30 \%$ in the immediate aftermath of the crisis to single digits to date enhances the attractiveness of the private pension scheme as a saving alternative. The participants of this scheme are able to retire at the age of 56 with a minimum participation of period of ten years. After then, they are entitled either to receive a lump sum payment on retirement or to take their total payment in the form of an annuity. The pension benefits depend mainly on contributions and their investment returns. Investments of participants are not taxed during the contribution period, however there are tax implementations for preventing them from opting out of the system before the vesting period. The total contribution in the system has amounted to 15 billion USD as of 2014 (Individual Pension System Progress Report of Turkey, 2014).

Turkish private pensions system has experienced notable growth right after the introduction of new incentives in 2011 to boost domestic savings. The new pension plan replaces the previous tax-deduction structure and encourages participants to make higher contributions to the system. The most noticeable improvement of the plan is that, the government matches $25 \%$ of individual contributions up to a gross monthly salary of about 500 USD, which is the minimum salary in Turkey. Meanwhile the regulatory authority coerces the pension companies to decrease their management fees and motivates new entrants to the sector to enhance the market competition.

In one of the notable studies, Smith (2006) investigate the payment persistency of individual pension plan participants in United Kingdom. The results of this study suggest that payment persistency is significantly related with the gender, earnings and income level of the participants. She concludes that participants with low income level struggle to match the pension plan payments even in the absence of income shocks.

It is plausible to focus on gender differences in payment persistence for the private pension scheme in Turkey. The savings of women typically have to be spread over a longer period of time since women live longer on average than men. Besides they must meet higher expenditures at the later stages of their lives since they experience more chronic health problems as they age. Therefore, women are more vulnerable than men to poverty in their older age. Moreover, substantial proportion of female employment in developing countries is in the form of short-term labor contract and casual, part-time work or home-based work (Sabates-Wheeler \& Kabeer, 2003). Generally, state perpetuates the male dominance over women through gender biased social polices (Quadogno \& Forbes, 1995). Similarly, Elveren (2013) defines the pension system in Turkey as "basing on a male bread-winner model where women are defined extensively as dependents". Despite relevant improvements in the Civil Code, the Labor Law and the Penal Code in early 2000's, Turkey's social security system does not cover the majority of women. Armed with these, women in Turkey need to accumulate more funds to independent pension entitlements. In the same vein, Romer (2001) indicates that greater the uncertainty about future income, the greater the saving. All together, we expect women to be more meticulous in payment patterns than men. However, it should also be taken in to account that, by covering the payments in 2004, Elveren and Hsu (2007) posit that in Turkey on the whole, women contribute less to their pension scheme than male mainly because women work fewer full time years than men. Again, for the year 2004, Elveren (2008) find for Turkey that relative to men, women receive lower pension benefits in a private pension system due to gendered division of labor in Turkey leading to lower earnings and shorter working period in the labor market. It 
should be underlined that according to the OECD statistics, Turkey has by far the lowest women's employment rate at $29.8 \%$ as of 2014.

Currently in Turkey, the portion of defined benefit system has been shrinking in overall retirement fund allocation. Therefore, a person's well-being in retirement tends to depend more heavily on their attitudes toward risk and the impact of those attitudes on investment decisions. Therefore, we investigate the role played by the risk level of invested funds in the pension scheme on the payment persistence. We predict that as the level of risk in investments increase, payments become more persistent.

The argument on risk can also be attributable to gender differences as well. Charness and Gneezy (2012) show that women invest less and appear to be more financially risk averse than men. Similarly, women exhibit greater relative risk aversion in their allocation of wealth into defined contribution pension assets (Bajtelsmit, Bernasek, \& Jianakoplos, 1999). Therefore, we are the first to investigate if the riskiness of investment portfolios has any role on payment persistence.

Kayam et al. (2013) report for Turkey that education level has a positive impact on not leaving the private pension scheme prematurely. Similarly, Van Rijckeghem and Ucer (2009) show for Turkey that as the education level increases, the savings rate rise as well. Moreover, in Turkey the education level is likely to improve the income-expense balance of households. Lastly, by studying the consumer credits in Turkey, Kucuktalasli et al. (2012) conclude that education has an increasing role in the likelihood of being a low-credit-risk customer given that they have more disciplined attitudes towards household expenditures. Consequently, we expect education to be positively associated with payment persistence for both genders.

Arslan and Karan (2009) find that in Turkey as the individuals age the eligibility of a household for consumer credit falls. Intuitively we expect the opposite for the persistence of private pension payments given that as the age of the individuals rise their payments become more persistent since they approach to their actual retirements.

While investigating role of demographics on the payment persistence of individuals, it is necessary to consider from which region of Turkey the participant is from (Note 1). The participants from the Eastern part of Turkey are most likely to leave individual pension scheme before retirement (Kayam et al., 2013). In terms of gender differences, urbanization plays an important role in the decrease of female labor participation, which is likely to have an effect on payment persistence of women. We expect the persistence to payment improve as the individuals live in urban areas.

The first study on the impact of marital status on private pension savings belongs to Johanisson (2008) who conduct analyses on the sample for Sweden. The author stresses that higher savings by married people is caused by the economic security tied to marital status. For this reason, married people allocate more savings to their private pension schemes. For the finding of higher savings by married women, the author assumes that married women usually are active in the labor market during a shorter period of time than married men because married men and women traditionally take different roles in both the labor market and in the family where men specialize in market production while women specialize in home production. Therefore, we expect a positive impact of being married on the payment persistence. We further posit that this positive impact is more pronounced for women because transferring parts of the household income to the wife's tax-deferred pension account becomes more important in a household.

\section{Data and Methodology}

The data is obtained from the one of the largest private pension firm of Turkey, Anadolu Hayat Emeklilik (AHE). The data is obtained from the firm by clustered sampling methodology. The original dataset includes several spreadsheets including demographic variables, payment history and also other information about the contract details. In the first step, we combine all of these spreadsheets to reach a final data set which includes all of the required information about the contract and contract holder. However, there are many missing values in the data set. Therefore, as a final step we delete the observation if it has any missing data related with any of the variables used in the analysis. Our final sample is a total of 6,025 customers having complete information about both demographic and socio-economics factors. The total number of male participants is 3,881 , while the number of female participants is 2,144 . The data for our analyses covers the payments made between January 31, 2004 and September 30, 2012.

We use logistic regressions to conduct our analyses which is formulated in Equation (1). In the equation, $\mathrm{p}$ represents the probability of an outcome, $\beta_{0}$ represent the constant term and $\beta_{1}$ is expected change in the log odds in response to one unit change in $X_{k}$ which represents the set of independent variables. Our estimations are based on dummy variables differentiated as those taking a value of one if they are persistent payers and those 
taking a value of zero if otherwise. We are able to access both declared and actual payments for each participant. For each month, individuals declare a predetermined amount which is can be considered as a projection about the future payments. In specific, we divide a participant's sum of all actual payments made to the private pension scheme to the sum of declared payments. If the ratio is equal to or greater than one than the variable takes the value of 1 and identified as the persistent payer. If the ratio is less than one than the dummy variable takes the value of zero, suggesting that the participant is not persistent. Accordingly, 2,039 participants out of 6,025 participants are persistent payers whereas the remaining 3,986 are classified as non-persistent payers.

$$
\ln \left(\frac{p}{(1-p)}\right)=\beta_{0}+\beta_{1} X_{k}
$$

Table 1. Definitions of the variables

\begin{tabular}{ll}
\hline Variable & Description \\
\hline Persistency & Dependent variable (Persistent=1, Non-persistent=0) \\
Age & Age of the customer when he/she enters into the system \\
Gender & Dummy Variable (Man=1, Woman=0) \\
Marital Status & Dummy Variable (Married=1, Single=0) \\
Education & Dummy Variable (Bachelor degree or more=1, otherwise=0) \\
Region & Dummy Variable (If the customer lives in İstanbul=1, otherwise=0) \\
Risk & Average risk level of the costumers' investment choice during the research period. \\
Contribution & Logarithm of the contribution of the customer decided at the beginning of the contract \\
Period & Total number of months customer stays in the system during the observation period \\
\hline
\end{tabular}

Table 1 provides the definitions of dependent and independent variables used in our analysis. Persistency is the dependent variables which takes the value of 1 for persistent participants and 0 for non-persistent ones. Age identifies the exact age when the participant entered in to the private pension scheme. Gender is a dummy variable taking the value of 1 if the participant is man and zero otherwise. Marital Status is also a dummy variable taking the value of 1 if the participant is married and zero if unmarried. Education variable takes the value of 1 if the participant has at least a Bachelor's degree and zero if otherwise. For the Region variable, we differentiate the individuals as the ones living in Istanbul, which take the value of 1, and the ones who live in any other city in Turkey but Istanbul, taking the value of zero. We took Istanbul as the reference point as the GDP per person of the residents of Istanbul is remarkably the country's highest and it is the industrial and financial center of Turkey ${ }^{1}$. The Risk variable shows the average risk level of the participant's investment choice. AHE's pension scheme provides 20 investments funds and they are segregated in to three different groups; namely, high-risk funds (HR), medium-risk funds (MR) and low-risk funds (LR). Each monthly payment of the participant is directed to these fund categories. While calculating the Risk variable; HR, MR and LR are coded as 2, 1 and zero respectively and weighted average of the allocation is the value of the Risk variable. For example; a participant allocated $50 \%$ of his monthly payment to HR, and the rest of $30 \%$ and $20 \%$ to MR and LR respectively. If the Risk variable is for a participant is equal to 1.3 , then it was calculated as; $(2 \times 50 \%)+(1 \times 30 \%)+(0 \times 20 \%)=$ 1.3. Consequently, the Risk variable takes a value between zero and two. The Contribution variable shows the monthly payment amount declared in the contact at the beginning of the private pension scheme and measured as the natural logarithm of that amount. Lastly, the Period variable is the total number of months that the customer stays in the private pension system. In our analysis we stipulated a customer remains minimum 12 months in the system to be included in our dataset to move on with the relatively persistent participants. 
Table 2. Summary statistics of the explanatory variables

\begin{tabular}{|c|c|c|c|c|}
\hline Variable (Continuous) & & Non-persistent $(0)$ & Persistent (1) & t-value \\
\hline \multirow[t]{5}{*}{ Age } & Mean & 34.820 & 36.27 & $-5.791 * * *$ \\
\hline & Std. Dev. & 9.162 & 9.219 & \\
\hline & Median & 33.000 & 35.000 & \\
\hline & Min. & 18 & 18 & \\
\hline & Max & 75 & 71 & \\
\hline \multirow[t]{5}{*}{ Risk } & Mean & 0.637 & 0.697 & $-4.359 * * *$ \\
\hline & Std. Dev. & 0.491 & 0.530 & \\
\hline & Median & 0.687 & 0.700 & \\
\hline & Min. & 0.000 & 0.000 & \\
\hline & Max & 2.000 & 2.000 & \\
\hline Variable (Continuous) & & Non-persistent $(0)$ & Persistent (1) & t-value \\
\hline \multirow[t]{5}{*}{ Contribution } & Mean & 4.787 & 4.911 & $-8.146^{* * *}$ \\
\hline & Std. Dev. & 0.518 & 0.630 & \\
\hline & Median & 4.859 & 4.977 & \\
\hline & Min. & 3.401 & 3.201 & \\
\hline & Max & 8.006 & 10.820 & \\
\hline \multirow[t]{5}{*}{ Period } & Mean & 39.740 & 48.540 & $-14.294 * * *$ \\
\hline & Std. Dev. & 21.052 & 25.365 & \\
\hline & Median & 35.000 & 47.000 & \\
\hline & Min. & 12 & 12 & \\
\hline & Max & 105 & 105 & \\
\hline Variable (Categorical) & & Non-persistent $(0)$ & Persistent (1) & Chi-square value \\
\hline \multirow[t]{5}{*}{ Gender } & Mean & 0.520 & 0.500 & $4.234 * *$ \\
\hline & Std. Dev. & 0.499 & 0.500 & \\
\hline & Median & 1.000 & 0.000 & \\
\hline & Min. & 0.000 & 0.000 & \\
\hline & Max & 1.000 & 1.000 & \\
\hline \multirow[t]{5}{*}{ Marital Status } & Mean & 0.700 & 0.740 & $12.851 * * *$ \\
\hline & Std. Dev. & 0.458 & 0.436 & \\
\hline & Median & 1.000 & 1.000 & \\
\hline & Min. & 0.000 & 0.000 & \\
\hline & Max & 1.000 & 1.000 & \\
\hline \multirow[t]{5}{*}{ Education } & Mean & 0.400 & 0.570 & $159.906 * * *$ \\
\hline & Std. Dev. & 0.491 & 0.494 & \\
\hline & Median & 0.000 & 1.000 & \\
\hline & Min. & 0.000 & 0.000 & \\
\hline & Max & 1.000 & 1.000 & \\
\hline \multirow[t]{5}{*}{ Region } & Mean & 0.340 & 0.390 & $13.150 * * *$ \\
\hline & Std. Dev. & 0.474 & 0.487 & \\
\hline & Median & 0.000 & 0.000 & \\
\hline & Min. & 0.000 & 0.000 & \\
\hline & Max & 1.000 & 1.000 & \\
\hline
\end{tabular}

Note. This table demonstrates key statistics of the variables used in the estimations. The number of non-persistent and persistent participants are 3986 and 2039 respectively. $* * *, * *, *$ indicate statistical significance at the $1 \%, 5 \%$ and $10 \%$ level, respectively.

Table 2 shows the descriptive statistics for our sample and the differences between the mean values of all the variables are statistically significant. On average, participants are nearly 35 years of age, medium risk takers, married and not from Istanbul, which contains around 19\% of the Turkey's population.

\section{Results}

The logistic regression results for the entire sample can be found in Table 3. First, we find that the likelihood of being a persistent payer is negatively related with being a man. Women are more meticulous in their payments to the private pension scheme because of more pessimistic outlook of the future for them and their relatively longer 
standing in the defined benefit system. Being married also increases the likelihood in the persistence. Aligning with the findings of previous studies for the creditworthiness of individuals, education also increases the probability of being a persistent payer. Despite having a relatively weak statistical significance, being located in Istanbul also raises the likelihood of persistency. Participants are found likely to be more persistent as their risk tolerance surges. Lastly, as the declared amount of payment and the amount of time remained in the system increases the possibility of being a persistent payer rise as well.

The finding that being a woman increases the likelihood of being a persistent payer reinforces the need to reiterate our analyses for the investigation of the impact of demographic and socioeconomic factors on the payment persistence of private pension installments through the segregation according to genders.

Table 3. Parameter estimates of the Logit model

\begin{tabular}{lllll}
\hline Parameter & Estimate & Wald Chi-Square & Significance & $\operatorname{Exp}(\beta)$ \\
\hline Constant & -3.473 & 180.649 & 0.000 & 0.031 \\
Contribution & 0.167 & 10.003 & 0.002 & 1.181 \\
Age & 0.013 & 16.550 & 0.000 & 1.013 \\
Gender & -0.179 & 9.738 & 0.002 & 0.836 \\
Marital Status & 0.223 & 10.923 & 0.001 & 1.250 \\
Education & 0.699 & 143.376 & 0.000 & 2.013 \\
Region & 0.133 & 5.041 & 0.025 & 1.142 \\
Risk & 0.381 & 42.186 & 0.000 & 1.464 \\
Period & 0.018 & 202.256 & 0.000 & 1.018 \\
Goodness of fit tests & Value & $p$-value & & \\
Negalkerke R Square $=$ & 0.105 & $\mathrm{n} / \mathrm{a}$ & & \\
H-L Significance $=$ & 3.387 & 0.908 & & \\
Log Likelihood $=$ & 476.498 & 0.000 & & \\
\hline
\end{tabular}

Note. This table demonstrates the estimated coefficients of the variables. The last column indicates the odds ratio. Significance of the model is tested by the Hosmer-Lemeshow Chi-Square test.

Table 4 reports the results after reapplying the analyses for women only. Total number of observations is 2,144. Firstly we find a positive association between being a persistent payer and being an older, more educated, higher risk taker participant and staying in the system for a longer period. However, our results are at odds with the previous finding about being located in Istanbul given that the coefficients representing these variables are found to be statistically insignificant. Women located outside of the industrial and financial center of Turkey is not found to be more encouraged to save more for their pension to fight against relatively less available opportunities. We also find that marital status does not have any impact for women's payment persistence. This is contrary to the finding by Johanisson (2008), that married women are likely to be more persistent payers given that they do not have the financial security of having a male as a breadwinner.

Table 4. Parameter estimates of the Logit model-Women

\begin{tabular}{lllll}
\hline Parameter & Estimate & Wald Chi-Square & Significance & $\operatorname{Exp}(\beta)$ \\
\hline Constant & -4.033 & 109.735 & 0.000 & 0.018 \\
Contribution & 0.303 & 14.505 & 0.000 & 1.355 \\
Age & 0.013 & 7.687 & 0.006 & 1.013 \\
Marital Status & 0.145 & 2.454 & 0.117 & 1.156 \\
Education & 0.686 & 67.108 & 0.000 & 1.985 \\
Region & 0.073 & 0.759 & 0.384 & 1.075 \\
Risk & 0.425 & 24.214 & 0.000 & 1.530 \\
Period & 0.018 & 92.066 & 0.000 & 1.018 \\
Goodness of fit tests & Value & $p$-value & & \\
Negalkerke R Square $=$ & 0.103 & n/a & & \\
H-L Significance $=$ & 13.680 & 0.090 & & \\
Log Likelihood $=$ & 3565.938 & 0.000 & & \\
\hline
\end{tabular}

Note. This table demonstrates the estimated coefficients of the variables. The last column indicates the odds ratio. Significance of the model is tested by the Hosmer-Lemeshow Chi-Square test. 
We report the impact of demographic and socioeconomic factors on the payment persistence for only the male participants in Table 5. Here, the total number of observation is 3,881. Our results here completely align with the results we obtained for the complete sample without a gender segregation. For men, the likelihood of being a persistent payer is positively associated with age, education, increase in risk tolerance and the total period remained in the system. In specific, only for male participants it is found that being married ensures the likelihood of being a persistent payer given the "breadwinner" role of men in Turkish society. Because being located in Istanbul is positively associated with the probability of being a persistent payer, the region is found to be only mattering for male participants.

Table 5. Parameter estimates of the Logit model - Men

\begin{tabular}{lllll}
\hline Parameter & Estimate & Wald Chi-Square & Significance & $\operatorname{Exp}(\beta)$ \\
\hline Constant & -3.163 & 78.325 & 0.000 & 0.042 \\
Contribution & 0.062 & 0.775 & 0.379 & 1.064 \\
Age & 0.012 & 5.717 & 0.017 & 1.012 \\
Marital Status & 0.321 & 9.872 & 0.002 & 1.378 \\
Education & 0.708 & 74.240 & 0.000 & 2.029 \\
Region & 0.193 & 5.217 & 0.022 & 1.212 \\
Risk & 0.345 & 18.541 & 0.000 & 1.413 \\
Period & 0.019 & 109.986 & 0.000 & 1.019 \\
Goodness of fit tests & Value & $p$-value & & \\
Negalkerke R Square $=$ & 0.109 & $\mathrm{n} / \mathrm{a}$ & & \\
H-L Significance $=$ & 13.559 & 0.094 & & \\
Log Likelihood $=$ & 3660.891 & 0.000 & & \\
\hline
\end{tabular}

Note. This table demonstrates the estimated coefficients of the variables. The last column indicates the odds ratio. Significance of the model is tested by the Hosmer-Lemeshow Chi-Square test.

To ensure the robustness of the estimations, we replicated our analyses by interacting the gender variable with education and marital status, respectively. However, none of our results are statistically significant than zero and hence not reported.

\section{Conclusions}

The retirement mechanism in both developed and developing countries is shifting from defined benefit schemes to the defined contribution systems. In this vein, Turkey also took necessary measures to encourage private pension schemes, mainly with an aim that these measures will have resonating impacts in deepening the domestic financial market. By studying the demographic and socioeconomic factors affecting the payment persistency of private pension installments in Turkey, we aim to enlighten the policy makers and financial institutions.

Our results show that overall being married, more educated, locating in Istanbul, being a risk tolerant individual, and also the amount of contributions and the total time remained in the system statistically significantly increases the likelihood of being a persistent payer. Interestingly our findings show that being a woman increases the likelihood of the persistency. Therefore, we reapplied our analyses by apportioning the sample as women and men. Our results completely align with those of the overall sample. However, we find for women participants that marital status and being located in Istanbul has no effect on the likelihood of being a persistent payer.

\section{References}

Akın, C.. (2012). Allocation of financial wealth in Turkey. Sermaye Piyasasl Dergisi, Special Edition on Financial Engineering and Risk Management, 2, 10-37. http://dx.doi.org/10.2139/ssrn.1331308

Arslan, Ö., \& Karan, M. B. (2010). Consumer credit risk characteristics: Understanding income and expense differentials. Emerging Markets Finance and Trade, 46(2), 20-37. http://dx.doi.org/10.2753/ree1540-496x460202

Bajtelsmith, V. L., Bernasek, A., \& Jianakoplos, N. A. (1999). Gender differences in defined contribution pension decisions. Financial Services Review, 8, 1-10. http://dx.doi.org/10.1016/s1057-0810(99)00030-x

Charness, G., \& Gneezy, U. (2012). Strong evidence for gender differences in risk taking. Journal of Economic Behaviour \& Organization, 83, 50-58. http://dx.doi.org/10.1016/j.jebo.2011.06.007 
Elveren, A. Y. (2008). Assessing gender inequality in the Turkish pension system. International Social Security Review, 61, 39-58. http://dx.doi.org/10.1111/j.1468-246x.2008.00309.x

Elveren, A. Y. (2013). A critical analysis of the pension system in Turkey from a gender equality perspective. Women's Studies International Forum, 41, 35-44. http://dx.doi.org/10.1016/j.wsif.2013.04.003

Elveren, A. Y., \& Hsu, S. (2007). Gender gaps in the individual pension system in Turkey. The University of Utah, Department of Economics, Working Paper, Issue 6.

Fershtman, C., Gneezy, U., \& List, J. A. (2012). Equity aversion: Social norms and the desire to be ahead. American Economic Journal: Microeconomics, 4, 131-144. http://dx.doi.org/10.1257/mic.4.4.131

Johannisson, I. (2008). Private pension savings: Gender, marital Status, and wealth: Evidence from Sweden in 2002 (Licentiate Thesis). Göteborgs Universitet, Sweden.

Karan, M. B., Arslan-Ayaydin, Ö., \& Alatl, M. (2009). Detection of factors leading to business failure for petroleum filling stations in Turkey. Iktisat, Işletme ve Finans Dergisi, 24, 9-26. http://dx.doi.org/10.3848/iif.2009.282.2489

Kayam, S. S., Parkın, M. K., \& Çeliktopuz, M. (2013). Features that influence the exit decision from the private pension system in Turkey. Munich Personal Repec Archive, No. 50933.

Küçüktalaslı, Ö., Arslan-Ayaydin, Ö., \& Karan, M. B. (2012). Quality in the financial sector from the perspective of consumer credits by socioeconomic and demographic characteristics. Total Quality Management \& Business Excellence, 23, 1453-1463. http://dx.doi.org/10.1080/14783363.2011.637799

Pension Monitoring Center of Turkey. (2012). Individual pension system progress report.

Pension Monitoring Center of Turkey. (2014). Individual pension system progress report.

Quadagno, J., \& Forbes, C. (1995). The welfare state and the cultural reproduction of gender: Making good girls and boys in the job corbs. Social Problems, 42(2), 171-190. http://dx.doi.org/10.1525/sp.1995.42.2.03x0109e

Rijkeghem, C. V. (2010). Determinants of private savings in Turkey: An update. Boğaziçi University. Department of Economics, Working Paper, No. 4.

Rijkeghem, V. C., \& Üçer, M. (2009). The evolution and determinants of the Turkish private saving rate: What lessons for policy? Economic Research Forum, Research Report.

Romer, D. (2001). Advanced Macroeconomics (2nd ed.). New York: McGraw Hill.

Sabates-Wheeler, R., \& Kabeer, N. (2003). Gender equality and the extension of social protection. Extension of Social Security Series, ESS Paper 16.

Whitehouse, E. R., \& Brook, A. (2006). The Turkish pension system: Further reforms to help solve the informality problem. OECD Social, Employment and Migration Working Papers, No. 44.

\section{Note}

Note 1. See, Karan, Arslan-Ayaydin and Alatli, 2009 for further discussions.

\section{Copyrights}

Copyright for this article is retained by the author(s), with first publication rights granted to the journal.

This is an open-access article distributed under the terms and conditions of the Creative Commons Attribution license (http://creativecommons.org/licenses/by/4.0/). 